\title{
1. Introduction: tax, law and development
}

\section{Yariv Brauner and Miranda Stewart}

This book is the first collection of independent academic scholarship exploring the relationship between tax, law and development. The innovative legal scholars who contribute to this book examine the role of law in national and international tax regimes and the uses of tax law in the universal quest for human development, across a range of topical tax issues. The book includes discussion of tax issues from the perspective of China, Brazil, South Africa, India and other developing countries. Contributors engage critically with economic, political, social and institutional approaches to tax, law and development. They discuss substantive tax laws that are central to economic globalization, such as tax incentives for foreign direct investment, and overarching themes, including tax equity in a global context and the processes of transnational tax law and administration. The editors have chosen to emphasize independence and a critical and pluralistic approach in the choice of essays. Nevertheless, the chapters are organized around four themes, each of which is discussed below.

First, the chapters in this book require us to acknowledge fully the unavoidable challenge of tax competition in a global economy. We must confront the tragic choices faced, in particular by developing countries, but in general by all countries, as a result of this challenge. It is the authors' view that we cannot avoid the challenge of tax competition by calls to end taxation of mobile capital even if this may be perceived to be a theoretical economic inevitability due to the difficulty of collection in an uncooperative environment. What is needed are new solutions, and perhaps solutions that can alter the environment itself as suggested by many of the essays in this book. At the same time, the arm's length rules for assessing tax on global business which are the prevailing norms are inadequate to the task. It is also foolish to assume that it will be possible to eliminate all tax havens, as if these were static or finite in number, or the only cause of global tax dilemmas. 
Second, these chapters call for us to abandon - or at least significantly downplay - the dominant normative approaches to tax policy for economic development. Instead, these chapters call for contextualized, diverse, partial and incremental tax law reform approaches. In this, the chapters are consistent with the 'new agenda for development' proposed by some development economists, notably Dani Rodrik and William Easterly, who take a more critical and nuanced approach to economic development. ${ }^{1}$ Rodrik and Easterly, with many others, have concluded that the dominant approach to economic reform of the international financial institutions, including the International Monetary Fund (IMF) and the World Bank, has not led to economic growth and, indeed, may have contributed to lower growth in some regions over the last 30 years. This approach has tended to involve the adoption of apparently complete, overarching, unitary and easily articulated solutions, or plans, based on global norms and limited local data (sometimes termed the 'Washington Consensus'). In the broad field of economic development and aid policy, they have called for an acknowledgement of diversity, and of 'many recipes' to produce successful results in particular countries.

Third, these chapters highlight the constantly disappearing goals of equity and redistribution in tax policy. The issue of equity both within and between nations is raised in several chapters. Equity is fundamentally linked to political legitimacy of tax law, especially to democratic accountability and hence to the sustained success of tax reform.

Finally, these chapters emphasize that international tax cooperation achieved through a range of informal and formal, incremental and top-down approaches - must be the way forward in reforming tax law for development. They raise questions about who participates in such international cooperation and how it is to be legitimated, and acknowledge the many difficulties and tensions in achieving such cooperation.

1 See, e.g., Dani Rodrik, One Economics, Many Recipes: Globalization, Institutions, and Economic Growth (Princeton, NJ: Princeton University Press, 2008); William Easterly (ed.), Reinventing Foreign Aid (Cambridge, MA: Massachusetts Institute of Technology Press, 2008); William Easterly, The White Man's Burden: Why the West's Efforts to Aid the Rest Have Done So Much Ill and So Little Good (Oxford: Oxford University Press, 2006); Joseph E. Stiglitz, Globalization and Its Discontents (New York: W.W. Norton \& Co., 2002); William Easterly, 'Can the West Save Africa?' (2009) 47 Journal of Economic Literature 373. 


\section{TAX REFORM AND FINANCING FOR DEVELOPMENT}

To date, scholars and practitioners who are engaged in the study and practice of human development have interacted with taxation via two different types of mission. The first mission has been the implementation of tax reforms to encourage economic development, in particular in so-called developing countries. One focus of tax reforms to generate economic development has been to devise tax laws that will encourage foreign direct investment into and exports from a market economy, while maintaining tax revenues, partly through shifting the tax burden to domestic consumption. The second mission has been to increase tax revenues so as to fund development expenditures and poverty relief. ${ }^{2}$ Tax reform with these goals has been a significant part of economic development projects since the Second World War.

There is now a substantial body of literature about tax reform projects, written by and for the reformers, including documentation produced by institutions such as the IMF, World Bank and the Organisation for Economic Co-operation and Development (OECD); expert reports for national governments; and academic commentary discussing the experiences, recommendations, and 'lessons' of tax reform projects. ${ }^{3}$ While

2 UN High-Level Panel on Financing for Development, Report of the High-Level Panel on Financing for Development: Recommendations, delivered to the General Assembly, UN Doc. A/55/1000 (2001) 3, 13, 15, available at http://www.un.org/reports/financing/report_full.htm ('the Zedillo Panel').

3 Among the many books on this topic are Richard Gordon (ed.), Taxation in Developing Countries: Six Case Studies and Policy Implications (New York: Columbia University Press, 2010). The first major collection on the subject was the Harvard Law School International Program in Taxation, Bibliography on Taxation in Underdeveloped Countries (1962) and see Richard Bird and Oliver Oldman (eds), Readings on Taxation in Developing Countries (Baltimore, MD: Johns Hopkins Press, 1964), since reissued on numerous occasions, see, e.g., Richard M. Bird and Oliver Oldman (eds), Taxation in Developing Countries (Baltimore, MD: Johns Hopkins Press, 1990). Other collections include Ehtisham Ahmad and Nicholas Stern (eds), The Theory and Practice of Tax Reform in Developing Countries (New York: Cambridge University Press, 1991); Richard M. Bird and Milka Casanegra de Jantscher (eds), Improving Tax Administration in Developing Countries (Washington, DC: International Monetary Fund, 1992); Malcolm Gillis (ed.), Tax Reform in Developing Countries (Durham: Duke University Press, 1989); Wayne Thirsk (ed.), Tax Reform in Developing Countries (Washignton, DC: World Bank, 1997); and Michael J. Boskin and Charles E. McLure, Jr (eds), World Tax Reform: Case Studies of Developed and Developing Countries (San Francisco, CA: ICS Press, 1990). 
global or cross-country influences are inevitable, national governments must play a central role in tax policy for development because tax reform requires enactment of laws, implementation by local bureaucracies and a level of acceptance by taxpayers. Tax reform projects may provoke a significant domestic political response, involving citizens either through the actions of representative government or through the actions of powerful domestic lobby groups.

Since the establishment of the Millennium Development Goals by the United Nations (UN) in 2000 and the Monterey Conference on Financing for Development held in 2002, the role of taxation in financing development has been widely emphasized. In 2002, the importance of tax reform was stated rather bluntly by the UN Panel on Financing for Development: ${ }^{4}$

Financing an adequate level of social public expenditure while limiting budget deficits calls for substantial tax revenues. Most countries of the developing world must undertake significant tax reforms if they are to raise the additional revenue that they need. These reforms should generally aim to broaden the tax base and to encourage domestic savings.

The dominant model of tax policy for economic development of the last two decades, implicit in the above quote, has envisaged a broad based tax system that reduces the tax on capital (thereby in theory encouraging savings) with low, flat corporate and personal income tax rates; the elimination of tariffs; and the establishment of a general Value Added Tax on domestic consumption, as well as some more specific resource or excise taxes. The state envisaged in global development discourse since the 1980s is a small, open-market oriented entity operating in the context of economic globalization, in contrast to the interventionist and often protectionist state of earlier decades. The most obvious example is the recommendation to reduce or eliminate trade tariffs, but other tax reform recommendations posited as inevitable in the face of economic globalization - e.g., the reduction or elimination of taxes on mobile capital (as opposed to less mobile capital such as labour, or fixed capital such as land) as a result of globalization of capital markets - also seem to reduce the power of the state.

The 2002 UN Panel was cognizant of the potential impact of raising taxation and constrained public spending on the poor, but emphasized the reducing fiscal deficits because, following the debt crisis of the 1980s, developing countries were forced to try to pay down their debts to

\footnotetext{
4 Zedillo Panel, supra note 2, at 15.
} 
international lenders. In practice, for most developing countries, the goal of increasing tax revenues was in conflict with their other main goal of tax reform for economic development. Many countries sought to achieve their goal of economic development by reducing tariffs and corporate tax rates and by enacting tax incentives, thereby reducing their ability to collect tax revenues. ${ }^{5}$ At the same time, there was an increasing need for government spending on poverty relief and in furtherance of development goals - such as education, health and infrastructure - as well as to ensure political acceptability of economic reforms. The resulting 'fiscal squeeze' has been widely recognized. Even the wealthiest developing countries, including China and India, face the challenge of this fiscal squeeze in a global context, as illustrated in a recent collection of country case studies. ${ }^{6}$

In 2011, the UN General Assembly, recalling the Monterey Conference, included the issue of financing for development in the provisional agenda for its 67 th session. ${ }^{7}$ The member states resolved:

to enhance and strengthen domestic resource mobilization and fiscal space, including, where appropriate, through modernized tax systems, more efficient tax collection, the broadening of the tax base and the effective combating of tax evasion and capital flight ... while each country is responsible for its tax system, it is important to support national efforts in these areas by strengthening technical assistance and enhancing international cooperation and participation in addressing international tax matters. ${ }^{8}$

The terms of the 2011 UN Resolution reveal a more subtle understanding of the complexities of the role of tax in the context of development. The member states placed the discussion of tax reform in the context of a 'global partnership' for development, and acknowledged the need for 'fiscal space'. The concept of 'fiscal space' refers to the combined role of tax and other sources of finance for the state, including borrowing. It implicitly acknowledges the need for countries to carry out development

5 This common pattern is demonstrated in Michael Keen and Alejandro Simone, 'Tax Policy in Developing Countries: Some Lessons from the 1990s and Some Challenges Ahead' in Sanjeev Gupta et al. (eds), Helping Countries Develop: The Role of Fiscal Policy (Washington, DC: IMF, 2004) 302-52.

6 See the case studies in Gordon, supra note 3.

7 UN General Assembly, Follow-up and Implementation of the Outcome of the 2002 International Conference on Financing for Development and the 2008 Review Conference, Report of the Second Committee (13 December 2011). See www.un.org/esa/ffd/ for more on the UN Financing for Development project.

8 Ibid. 3. 
spending in spite of fiscal constraints. The Resolution acknowledges that tax reform should be adopted 'where appropriate', the implication being that tax reform is not always the right - or only - solution. It emphasizes that national tax systems operate in a global context, thus focusing on cross-border tax evasion, international cooperation and participation in the international tax system. However, the 2011 Resolution still does not engage - in its brief terms - with the varied and contradictory reality of reforming tax laws for development.

A clear theme of all the chapters in this book concerns these common difficulties and practical challenges that developing countries face in enacting and implementing effective tax laws in their quest for development, in each country's own unique context. These challenges include technical challenges related to the general legal framework of domestic legal systems, administrative challenges associated with collecting tax, and the challenge of enacting laws that interact with an international tax regime that is highly influential yet does not have a superior status to domestic laws. This raises further systemic questions. Has the international tax regime already risen to the level of customary international law, ${ }^{9}$ and if so, what are the implications of this for developing country tax reform? Is it possible to coordinate tax policies in a world that is currently dominated by tax competition rather than cooperation between countries regarding their tax policies and enforcement? Finally, it must be noted that a similarity of challenges does not necessarily mean similarity of appropriate solutions. To what extent should differences between countries play a role in the design of solutions and methods for development? This theoretical critique and the potential for alternative solutions is clear in many of the essays in this book. The legal perspective that is essential for the implementation of economic theories for people and societies strongly illuminates the necessity of change in our approach to development approaches in general, and economic development viewed through a tax law prism in particular.

\section{TAX COMPETITION AND TRAGIC CHOICES}

The mission of reforming tax systems to encourage economic development has emphasized the use of incentives for investment based on

9 Reuven Avi-Yonah, International Tax as International Law (New York: Cambridge University Press, 2007); but see Brian D. Lepard, Customary International Law: A New Theory with Practical Applications (New York: Cambridge University Press, 2010). 
simplistic market theories, resulting in an impressive variety of tax incentives for investment in developing country tax systems. The widespread use of tax incentives to encourage foreign direct investment is premised on a series of weak assumptions. ${ }^{10}$ These assumptions about the role of investment in economic growth; the importance and value of foreign direct investment in such growth; and the responsiveness of such investment to tax incentives, are shown by Yariv Brauner in Chapter 2, 'The future of tax incentives for developing countries' to be false, or else to be weak at best. Brauner explains that tax incentives are prevalent in both the developing and developed world, yet their story is more about tax competition than about growth and development as may be implied from the standard rhetoric in support of their use. This chapter explores what we know and do not know about tax incentives, and emphasizes the striking lack and weakness of available relevant data, which leads us to much doubt about their efficacy. It further examines how tax incentives may be reformulated to assist countries in their quest for development, highlighting the potential benefits to productive countries of coordination and the important role of developed countries in assisting such a process. Finally, the chapter advocates a reform of the way we approach development, supporting the new development agenda, referred to above, in contrast to current practice of the largest international and some aid based organizations.

The reliance on tax incentives in a globalized world, ironically, perpetuates for many developing countries the form of economic development strategy of an earlier era, but now focusing on foreign investment. After the Second World War, many developing countries adopted a strategy in which the state had the role of managing the process of economic growth, through giving high priority to the goals of industrialization, diversification and modernization. ${ }^{11}$ For tax policy, this meant tariff protection for domestic industry, input subsidies, and favourable domestic tax regimes (containing tax concessions or incentives) for industry. Such favourable regimes were limited to domestic investment, as cross-border capital investment was relatively limited in the context of capital controls and an immature global financial system. Between the 1950 s and the 1970s, tax policy was promoted as a legitimate means of

10 An illustration of the continued importance of tax incentives in developing countries in the Asian region is provided by the Asian Development Bank database of regional country tax incentives, searchable on its website: www.aric.adb.org/tax incentives.php.

11 Dharam Ghai, 'Introduction' to The IMF and the South: The Social Impact of Crisis and Adjustment (London: Zed Books, 1991). 
intervention in the development process and taxes (and tax incentives) designed to direct firms and individuals into particular investments and activities were a key part of development policy. ${ }^{12}$

Developing countries persist in the use of tax incentives because of the trap of tax competition. This runs counter to the policy prescriptions of the IMF and other international organizations and experts, who repeatedly point out the problems inherent in such a tax incentive strategy. Yet, it is a rational response to the current global environment. In Chapter 3, 'The tragic choices of tax policy in a globalized economy', Tsilly Dagan explains that classic goals of income tax policy are affected by global tax competition among states for capital and residents. Global tax competition 'renders tentative and conditional everything from efficiency to redistribution and even the very concepts of community, national identity and democratic participation ... The state no longer only makes compulsory demands on its subjects in order to promote the collective goals of a given group. Instead, the state increasingly acts as a recruiter, to solicit investments as well as residents from the global arena.' ${ }^{13}$ Tax legislatures are pushed to limit states' redistribution functions; they are required to choose between their current or historical group of citizens and others possibly more attractive ones; they abandon democratic participation traditions of voice for exit-based practices; and they undermine classic ability to pay considerations, stressing mobility in their stead. Dagan raises the fundamental challenge that we must rethink both democratic accountability and distribution if we are to succeed in national tax reform to support development in a global context.

The enactment and goals of a specific tax incentive, a regional headquarter company regime, is examined by Tracy Gutuza in Chapter 4, 'Economic development and the role of tax in Southern Africa: the South African headquarter company structure'. Gutuza demonstrates that what seems to be a recent development has longstanding historical roots within South Africa since before the 1994 democratic regime. This tax reform is connected to the country's perceived role as leading and facilitating economic development in the region, while also competing with other tax incentive regimes, such as that in Mauritius. Tax reforms since 1994 have sought, among other things, to place South Africa in a strong position within the world economy, broaden the South African tax base and incentivize certain types of investment, in particular foreign direct

12 Malcolm Gillis (ed), Tax Reform in Developing Countries (Durham: Duke University Press, 1989) 19-20.

13 See Tsilly Dagan, Chapter 3. 
investment. These reforms are clearly designed to support South Africa's economic development. Further recent changes include the introduction of withholding taxes on dividends and interest. The recently enacted non-resident headquarter company regime was introduced so that South Africa can be the gateway into Africa for foreign investors. It is intended that these changes will assist in attracting foreign direct investment into South Africa and also into Africa. In addition to these tax reforms, South Africa is also a party to NEPAD (the new partnership for African Development), under the auspices of the African Union. Gutuza's essay critically analyses these tax reforms undertaken by South Africa in the light of the development goals of both South Africa and regional initiatives such as NEPAD. In so doing, the chapter also considers normative proposals for tax law reform in a developing country regional context.

A common issue that arises when tax incentives are considered as a matter of national tax policy of developing countries is how these incentives interact with the international tax regime. In particular, an issue arises as to approaches to tax relief for cross-border investment in national law or bilateral tax treaties. Luís Eduardo Schoueri in Chapter 5, 'Tax sparing: a reconsideration of the reconsideration', analyses the role of tax sparing clauses in treaties. This direct measure that developed countries adopt on a fairly regular basis in the context of development and assistance to developing countries is generally perceived to be an exercise of foreign aid to support development - perhaps, to ease the global tax system with the injection of some equity. Such tax sparing clauses have been criticized by the OECD, and by several developed countries (most notably the United States) which tend to oppose their inclusion in tax treaties. Schoueri's chapter discusses the main arguments presented by the OECD against the use of tax sparing and proposes a new approach to tax sparing clauses that will validate their use, on the basis, not of international aid, but of sovereignty of taxing rights in developing countries. He argues that a decision by a developing country to enact a tax incentive is an exercise of its own right to tax on a source basis the activity or investment in the host jurisdiction. Such a decision by the host government does not entitle the residence, or investor home country, to levy tax on the profits from that investment, in the place of the host country government. Schoueri thereby challenges some of the current international tax norms as structurally embedding a hierarchy in which capital-exporting, developed countries will always benefit more, from a tax perspective, from the policy responses of developing countries seeking to encourage mobile foreign direct investment. 


\section{IN SEARCH OF 'SEARCHERS' TO FIND UNIQUE SOLUTIONS TO COMMON TAX CHALLENGES}

Tax reform may be considered a 'speciality' of public finance or economic policy. ${ }^{14}$ Tax reform is also law reform that almost always involves 'transplanting' legal notions or models across borders and hence may be theorized as a comparative law project. ${ }^{15}$ Finally, tax reform can be thought of as an element of 'governance' reform with its focus on institutions, administration and (re)construction of modes of interaction of citizens and the state. ${ }^{16}$ All of these aspects have been the focus of tax reform attention in the last few decades, in line with generalized tax policy, legal and governance prescriptions. Yet, in spite of this substantial effort, the difficulties - many argue widespread failure - to achieve successful tax reform has been acknowledged and discussed by many. While there have been successes, a closer look frequently indicates a more uneven performance and continuing challenges faced by governments. ${ }^{17}$

The failure of many tax reforms to achieve sustainable revenues and support economic development can be understood in the context of wider failures in economic reform for development, or in planning for poverty relief. Such failures have been until recently explained by international institutions and development experts as the result of governmental weaknesses and macroeconomic mismanagement in developing countries. However, it has become increasingly clear that the factors that affect the process of development are genuinely complex and diverse. The 'new' approach to development discussed in Part I above requires a different approach to finding solutions, including tax reform solutions.

In the context of poverty relief and international aid, Bill Easterly has argued that poverty can only be ended by 'searchers', both economic and

14 Richard Bird, Tax Policy and Economic Development (Baltimore, MD: Johns Hopkins University Press, 2002) 183.

15 See Alan Watson, Legal Transplants: An Approach to Comparative Law (Athens, GA: University of Georgia Press, 1993) 19-20.

16 Global Governance Reform Project, Reimagining the Future: Towards Democratic Governance (Saint Kilda/VIC: Vista Publications, 2000) 14; Michael J. Trebilcock and Ronald J. Daniel, ch. 6 'Tax Administration' in Rule of Law Reform and Development: Charting the Fragile Path of Progress (Cheltenham, UK and Northampton, MA, USA: Edward Elgar, 2008).

17 See, e.g., Gordon, supra note 3. 
political. Searchers have the following characteristics, which are worth setting out in detail: ${ }^{18}$

'Searchers' ... explore solutions by trial and error, have a way to get feedback on the ones that work, and then expand the ones that work, all of this in an unplanned, spontaneous way. Examples of searchers are firms in private markets and democratically accountable politicians ... Searchers do not set predetermined problems and do not have big plans; they are just on the lookout for favorable opportunities to solve problems - any problem no matter how big or small, whose solution will benefit themselves or others. Searchers must learn enough about each little problem to solve it, which means they must get feedback from the people affected by the problem and what they need to fix it.

Easterly contrasts the 'searcher' approach to the 'planner' approach which assumes that the problem is known, and can be planned for, and that technical solutions exist for all contexts. Dani Rodrik would retain the insights of economics but calls for an end to 'advice based on simple rules of thumb, regardless of context'; for 'a careful reading of the empirical evidence' of economic development in particular countries; for an acceptance of a significant role for government in development; and for 'modesty' in recommendations for change in constrained contexts. ${ }^{19}$ He also emphasizes the importance of institutions and most importantly of 'participatory government' - like Easterly, highlighting the role of democratically accountable politicians in sustainable economic growth. ${ }^{20}$ Rodrik is more likely to support planning than Easterly, and is cautious about experimentation, but he would also always acknowledge the need for context-specific, locally accountable reforms evaluated according to local evidence.

In tax policy for development, as in other development policy arenas, a 'one size fits all' approach has dominated. In particular, the IMF has pushed forward 'one size fits all' type tax reforms. ${ }^{21}$ The OECD and IMF have, more recently, promoted uniform approaches to budget laws and

18 Easterly, Reinventing Foreign Aid, supra note 1, at 6-7.

19 Rodrik, supra note 1, at 3-5.

20 Ibid. at 169.

21 Miranda Stewart and Sunita Jogarajan, 'The IMF and Tax Reform' (2004) 2 British Tax Review 146; Miranda Stewart, 'Tax Policy Transfer to Developing Countries: Politics, Institutions and Experts' in Holger Nehring and Florian Schui (eds), Global Debates about Taxation (Basingtoke: Palgrave Macmillan, 2007) 182-200. A recent acknowledgement of the 'checkered history of big ideas' in tax reform is made by Michael Keen of the IMF, in 'Taxation and Development - Again', IMF Working Paper WP/12/220 (September 2012). 
fiscal transparency, including tax expenditures. ${ }^{22}$ As in the general development context, historically at least, the failure of tax reform projects has been attributed to internal causes and not to the tax reform process itself. For example, the World Bank has observed that a number of problems of domestic country governments (including the perception that resistance to tax reform is insurmountable, the inability to understand the technical nature of the expert advice, the lack of familiarity with the issues, and changing economic conditions) impede the implementation of the Bank's technical tax advice. ${ }^{23}$ Yet there are several more significant and interesting explanations of failure in reform.

First, as indicated in Part II above, and in the chapters of Brauner and Dagan, the failure of tax reform is a consequence of the 'tragic choices' which countries face in reforming their tax systems in unsustainable ways and impossible time frames, given global economic pressures and tax competition. Failure of countries to mobilize adequate tax revenue is not solely explainable by poor domestic governance, but is a consequence of the contradictions of development in a globalized world. In the face of such difficulties, a country may not be able to 'develop' in spite of attempts to carry out reforms and a global hierarchy of developed and developing countries will be perpetuated. Countries will continue to enact tax incentives in apparent defiance of institutional recommendations, if those recommendations continue to be made in isolation of wider global economic pressures. Enterprises and governments of the developed world continue to pressure developing countries to open markets, to provide concessions, and generally to become attractive targets for Western-based corporate investment. Tax reformers need to promote a new vision of the state that encourages cooperation between states, not merely in bilateral tax treaties (which may not provide much economic benefit), but in decision-making about domestic tax regimes that will benefit countries in the long term.

Second, failure of tax policy or law reform may indicate unwarranted haste or, more seriously, a mismatch or misunderstanding by tax reformers of the fit between particular tax reform proposals and the law, legal culture and broader social and economic context in which they are

22 IMF, Manual of Fiscal Transparency (Washington, DC: International Monetary Fund, 2007); OECD, 'Best Practices for Budget Transparency' (2002) 1(3) OECD Journal on Budgeting 7; Lisa Philipps and Miranda Stewart, 'Defining Fiscal Transparency: Transnational Norms, Domestic Laws, and the Politics of Budget Accountability' (2009) 34(3) Brooklyn Journal of International Law 798.

23 World Bank, Lessons of Tax Reform (1991) 74-5. 
applied. In particular, problems in ongoing enforcement may be the result of importation of inappropriate tax laws or mass-produced policy prescriptions. Empirical research on the effectiveness of transplanted laws, including 'the massive importation of legal code' into the transition countries commencing in the late 1980s (of which tax code formed a part), supports this criticism of the wholesale 'model' approach to tax reform. ${ }^{24}$ The evidence suggests that subsequent enforcement of transplanted law is weak and problematic, in particular where the transplanted legal code does not fit the history of development of legal structures in the recipient country. ${ }^{25}$ Several chapters in this volume consider tax law and governance institutions, and the role of law itself in tax reform, from different perspectives. The essays emphasize the local context and inquiring as to what would be the actual effect of particular reforms.

There has been little self-reflexive analysis by tax law experts of their own position and approach to legal drafting and transplantation in developing countries. In Chapter 6, 'Is this a pipe? Validity of a tax reform for a developing country', Ana Paula Dourado presents a deep theoretical examination of the work and role of an external tax law drafter, who must operate between global norms of tax policy and plural domestic legal and tax regimes. She engages directly with the existential challenge: how to be a 'good' tax legal expert, acting at the intersection of the global and the local and seeking to ensure ownership, legitimacy and effectiveness of a tax reform. Her reflection carries particular weight in light of the author's hands-on experience with local country tax reform in the context of an international financial institution. To highlight the problems of mass solutions or 'model' codes is not to reject learning from experience, or the value of applying a tried and tested model instead of outright experimentation. Dourado's experience demonstrates that a diversity of approaches can be accommodated within more general tax reform principles, but, as she explains, general principles must always be tailored to fit the specific legal and tax cultures of each country.

A careful examination of a particular context may also reveal an unexpected role for law in general, or tax law in particular, in a particular country, with implications for approaches to tax reform. In Chapter 7, 'The place of law in the evolution of Chinese fiscal federalism', Wei Cui examines the role of law itself in one of the most important tax reform

24 Daniel Berkowitz et al., Economic Development, Legality and the Transplant Effect, Centre for Law and Economic Studies, Columbia Law School Working Paper No. 195 (2001) 7-10, available at www.law.columbia.edu/laweconomicstudies/papers/wp195.pdf.

25 Ibid. 
contexts in China, that of the allocation of taxing powers among national and sub-national governments. He asks what role is played by tax law, as distinguished from the tax policies that it embodies more or less perfectly, in either enhancing or hindering fiscal federalism in China? Cui observes that many developing countries in search of appropriate tax policies also have fledgling legal systems and in these countries, a legal including constitutional - framework for developing and implementing tax legislation cannot be taken for granted. While the law is often rhetorically treated as barely deserving of attention by China's tax policy-makers and their academic advisors, Cui suggests that legal institutions and mechanisms were important tools for the government in building tax administration where almost none had existed before and the law was used rhetorically by the central government to advocate and promote central government control in an era of decentralization. The analysis highlighting the role of the law itself is particularly interesting in the context of China, where the 'Western' conception of the rule of law is still only in its early stages. At the same time, China's acknowledged role as a leader among developing countries appears to be generating pressure for reform of the international tax law regime. Together with similar empowerment of the other emerging economies (in particular, the 'BRICS' - Brazil, Russia, India, China and South Africa), this opens a window of opportunity for genuine reform of the international tax regime in a manner that would consider fairness and development together for the first time.

Moving away from the role of tax law itself in a country's path to development, Lisa Philipps in Chapter 8, 'The globalization of tax expenditure reporting: transplanting transparency in India and the Global South', considers an aspect of fiscal or budgetary governance. Her chapter examines the challenges for low and middle income countries of undertaking tax expenditure analysis, which has been practised in OECD countries since the 1970s. A range of scholars and organizations have advocated for countries of the Global South to emulate these reporting practices in order to increase fiscal transparency and improve policymaking. The chapter reviews available evidence about current practices among developing countries and finds there is a trend toward more tax expenditure reporting. Somewhat ironically, however, the literature in OECD countries is rife with concerns and disappointments about whether tax expenditure reporting has achieved its alleged benefits. Philipps considers the potential benefits but also the challenges and problems that may arise in transplanting tax expenditure budgeting practices crafted in OECD countries to other economic, political and legal contexts. She then 
takes a closer look at the recent experience of India, which has developed a tax expenditure report within its Union Budget.

\section{TAX EQUITY, REDISTRIBUTION AND AID}

In this global tax competitive world, how are we to understand tax policy principles of equity and redistribution? There is a link between the failure of tax reform and concerns about the equity, legitimacy or 'ownership' of tax reform. Some of our authors seek to draw closer together the discourse on substantive international tax law and norms, with development goals of freedom, human rights and alleviation of inequality.

Tax reform projects are frequently constructed in such a way as to remove them from the domain of domestic politics. Subtly, but pervasively, tax reform may be cast by external agencies as an essentially technical project which does not raise issues of politics at all. A tax reform may be required or recommended as a result of international negotiations conducted by the executive of the country, or it may be part of the conditions of a structural adjustment package that is not approved up front through the political mechanisms of the state. Consequently, failure of legal and administrative tax reform may be a result of the lack of ownership of the law, policies or processes by government executives, bureaucracies and political agencies in developing countries. Failure of tax reform may also be evidence of serious dissent among the population with respect to the specific reform or economic reforms more generally. ${ }^{26}$ Yet taxation is inherently political; fiscal policy reform is "central to the nation itself', as it 'shifts resources from one segment of society to another, directly or indirectly, intentionally or unintentionally ... such decisions are political at their core'. ${ }^{27}$ Ultimately, sustainable tax reform requires the continual (re)negotiation of 'fiscal compacts' about the fairness of tax law and distribution of the tax burden. ${ }^{28}$

26 See, e.g., the reform of the VAT in Ghana, discussed in Stewart, supra note 21.

27 UN World Economic and Social Survey 1997, at 65.

28 Margaret Levi, Of Rule and Revenue (Berkeley, CA: University of California Press, 1988); Mick Moore and Lise Rakner, 'The New Politics of Taxation and Accountability' (2002) 33(3) International Development Studies Bulletin 1; OECD, Governance, Taxation and Accountability: Issues and Practices, DAC Guidelines and Reference Series (Paris: OECD, 2008), available at www.oecd.org/dataoecd/52/35/40210055.pdf. 
Tax reform is concerned with strengthening the position of the state so that it can both further the goal of economic development and provide a buffer for its people against globalization, paying attention to so-called 'core activities' of infrastructure and poverty relief supported by an increase in its taxing capacity. ${ }^{29}$ Developing countries are particularly vulnerable to the harms of economic globalization, in part because they do not begin with strong tax systems. ${ }^{30}$ Yet they face the biggest hurdles in constructing effective tax systems in the face of economic globalization. ${ }^{31}$ Collective action challenges are particularly severe in respect of attempts to generate international cooperation in tax matters, in particular on fairness-related issues.

Anthony Infanti's Chapter 9, 'Internation equity and human development', is directed to the problem of global fairness in taxation. Infanti takes on the challenge of developing the path-breaking work of Richard and Peggy Musgrave first proposed in 1969.32 Since then, as Infanti observes, although some have engaged with the concept of internation equity, it has remained rather thin and has not been particularly tractable to substantive analysis. ${ }^{33}$ Discussions of internation equity are typically framed in terms of allocation of the tax base or redistribution of tax revenues between richer (i.e., 'developed') and poorer (i.e., 'developing') countries. In respect of the tax base, a debate around definition of the jurisdictional allocation, primarily, defending the right of a source state to tax income which results from activities within its borders, is in any

29 Vito Tanzi, 'Changing Role of the State in the Economy' in Policies, Institutions and the Dark Side of Economics (Cheltenham, UK and Northampton, MA, USA: Edward Elgar, 2000) 20-22.

30 Vito Tanzi, 'The Impact of Economic Globalization on Taxation' (1998) International Bureau of Fiscal Documentation Bulletin 338.

31 See, e.g., Vito Tanzi and Howell H. Zee, Tax Policy for Emerging Markets: Developing Countries, IMF Working Paper No. 35 (2000) 29-30, available at www.imf.org/external/pubs/ ft/wp/2000/wp0035.pdf; Sven-Olef Lodin, 'Outline of the Symposium' in Visions of the Tax Systems of the 21st Century, International Fiscal Association Jubilee Symposium (IBFD, 1996) 4.

32 Richard A. Musgrave and Peggy B. Musgrave, 'Inter-nation Equity' in Modern Fiscal Issues: Essays in Honor of Carl S. Shoup (Toronto: University of Toronto Press, 1972) 63.

33 An exception is Kim Brooks, 'Inter-nation Equity: The Development of an Important but Underappreciated International Tax Policy Objective' in John G. Head and Richard Krever (eds), Tax Reform in the 21st Century: A Volume in Memory of Richard Musgrave (Alphen aan den Rijn: Wolters Kluwer Law \& Business, 2009) 471, 472. 
event a central question of international taxation. This does not significantly advance the internation equity debate in the context of global development goals, although it must be acknowledged that source (capital-importing) states must constantly fight to maintain their source taxation base. The Musgraves also raise the possibility that internation equity might enable international redistribution, acknowledging the highly unequal distribution of resource endowments and per capita GDP among countries. To achieve this, they propose a corporate tax rate tied to the per capita income of both the capital-importing and capital-exporting states. As is seen in the chapters of this book that discuss tax incentives for foreign direct investment, this proposal has never been achieved and indeed, the opposite seems to be the result.

Infanti explains that even the Musgraves' 'redistributive' approach to internation equity focuses solely on the economic dimension of states, just as discussions of inter-individual equity tend to focus solely on the economic dimension of individuals and ignore other lines of difference (e.g., race, ethnicity, gender, and sexual orientation). But, as is true of individuals, the relative economic status of a nation is but one aspect of its development. Infanti points out that elsewhere in the development context, a broader notion of wellbeing or equity that is 'people-centred' rather than income-centred has been recognized since Amartya Sen worked on the first Human Development Index in 1990. ${ }^{34}$ Infanti proposes that a developed country's tax credit, exemption or corporate tax rate rules for international investment could be linked, in various ways, to the HDI or aspects of it. Infanti's analysis widens the debate in two important ways. First, it situates the international tax rules of a country (such as the United States) in the wider context of its foreign policy and international aid and development programme. Second, it situates the internation tax equity debate in the wider context of international development equity, and seeks to link tax rules to country performance on a wider measure of human development. The difficulty remains, how to carry out the proposal in the context of the current international tax norms of reciprocity and bilateralism and of other policy goals of countries in setting their investment tax settings.

In Chapter 10, 'The role of developed world tax incentives in microfinance', Charlene D. Luke also turns her lens on developed country tax laws, in particular the United States. Luke focuses on microfinance as an element of aid policy and how this intersects with domestic US tax law.

34 The approach elaborated by Amartya Sen, Development as Freedom (New York: Anchor Books, 2000). 
In response to calls for developed countries to assist with development or poverty relief, developed country tax law reforms may be proposed that could support international aid. Luke examines one of the most unique, innovative and specific devices for economic development, microfinance, and discusses whether and how the US tax system could be reformed to strengthen the microfinance sector in developing countries. She points to the links between tax subsidies for international charitable giving and aid, and for international investment, and discusses the ways in which current US tax law may support or impede microfinance. Luke is cautious, however, as to whether further US tax subsidies for microfinance are warranted, in particular given the complexities and contradictory views concerning the different forms of microfinance programmes themselves within developing countries. Luke's article serves as a topical example for an implementation of the new development agenda and an example for the type of detailed examination of evidence it requires, in the tax context.

\section{TAX COOPERATION}

The theme of tax competition, however one defines it, and the need for some form of international cooperation and coordination of tax policies distinctly emerge from many of the essays in this book. The painfully slow process of such international tax coordination has been well documented by others. This Part includes chapters that take a visionary approach to the allocation of taxing powers in the international tax system, and more specifically related to the current 'hottest' issue on the international tax agenda - the coordination of policies regarding the critical issues of exchange of information and good tax governance in general.

In Chapter 11, 'Geographical boundaries of tax jurisdiction, exclusive allocation of taxing powers in tax treaties and good tax governance in relations with developing countries', Pasquale Pistone discusses whether the geographical boundaries of tax jurisdiction can be reconsidered in the treaty relations of developed countries with developing countries, in such a way that developing countries would remain masters of their own international tax policy decisions. This chapter queries whether the generally perceived 'best practice' of international tax principles established in the OECD Model Convention is really appropriate for developing countries, focusing in particular on the foreign tax credit method for relieving double tax (where applied especially to active business profits). Instead, Pistone considers a possible shift to an exclusive allocation of taxing powers over business and other forms of income to developing countries, 
or, at least for some types of income, a shared allocation of tax jurisdiction combined with non-compensatory methods for relieving double taxation in tax treaties. The chapter considers these specific issues in the broader context of good tax governance that is a dominant theme in EU and OECD documents on developing country tax relations. The concrete substance and standards for 'good tax governance' have not yet been clearly defined, although most work has been done to date on international tax information exchange procedures. The author reminds us that, again, it is important to consider what is good tax governance in terms of principles and practicalities, from a developing country tax perspective.

Allison Christians in Chapter 12, 'Tax activists and the global movement for development through transparency', identifies and explores the rise of a 'civil society' or non-governmental organization (NGO) movement for tax transparency in a global context. The chapter builds on Christians' substantial previous work analysing processes, players and institutions in tax policy at a global level. Christians has previously argued that poor countries are effectively absent from key intergovernmental organizations that create and disseminate global 'soft' tax models, norms and guidance, making them 'takers' rather than 'shapers' of global tax policy. In this volume, Christians traces the development of the tax transparency movement over the last decade. The movement grew out of anti-corruption activism, which led initially to some success in the resources industry sector with 'Publish What You Pay' advocacy and the establishment of the Extractive Industries Transparency Initiative.

The transparency tax movement has a number of striking features that may indicate the gradual development of a global tax politics engaging citizens of diverse states, but Christians' analysis also reveals that many obstacles remain to establishing such a global politics. First, the movement brings together NGOs and activist groups in developed countries with some citizen movements in developing countries, to engage with global institutions and multinational enterprises. Tax has long been a black box to development and aid activists; this movement begins to open that up to citizen scrutiny. Second, the movement differs from the resource sector initiative in that it directly engages with the concept of a 'fair share' of taxation for a particular country, or its citizens. The movement is not only about extracting an appropriate price for a non-renewable resource (which is, of course, a crucial matter for citizens in resource-rich countries). Although its focus is on transparency, it has potential to impact upon the fundamental questions of the substantive tax base including transfer pricing, tax incentives and the allocation of taxing jurisdiction between states. 
Finally, Miranda Stewart in Chapter 13, 'Global tax information networks: legitimacy in a global administrative state' evaluates transnational cooperation in tax information exchange, and the enforcement and collection of taxes. She identifies the increasingly tight and legalized networks of transnational tax administration, in light of significant recent developments primarily between developed countries and institutions such as the OECD and EU. She then asks whether and how these networks can be extended to benefit developing countries and to bring to account multinational corporate actors and banks. It is postulated that transnational tax networks are slowly concentrating or agglomerating into a global tax bureaucracy 'from the ground up'. If this is true, how can we ensure accountability and legitimacy of this new bureaucracy? To answer this crucial question, this chapter examines forms of legal and political accountability that originate in classic hierarchical modes of governance, to see if they can be adapted to fit the new transnational tax networks.

The variety of chapters presented in this book forcefully demonstrate the deep need and the wealth of opportunities for progress in this avenue of study of tax, law and development. The primarily economic and 'one size fits all' focus of tax policy to date has not been sufficiently matched by detailed legal, historical and contextual policy analysis that can fortify and enrich it, supporting the implementation of tax reforms within real world social and legal structures. A range of alternative approaches to development arise out of the critique presented by the authors in this book and surveyed in this Introduction. The chapters call for a direct acknowledgement of the challenges and contradictions of tax law reform for development, and emphasize patience, diversity, a trial-and-error approach, transparency, legitimacy or 'ownership' and constant feedback and evaluation in tax reform approaches. Although less apparently streamlined and 'correct', these alternative approaches to tax, law and development do not imply a loss of focus, ${ }^{35}$ even if they are slow, difficult to implement, and lack the appeal of promised panacea. Moreover, they often require careful coordination within and between countries that does not exist in the current international tax regime. This new approach does, however, promise some actual success. The goal of this book is unashamedly idealistic, to serve as the foundation that would jump-start further scholarship, and support real change in the global and national tax laws for economic development.

35 Ibid. 